\title{
Ungkapan Bermakna Budaya Dalam Upacara Meminang Gadis Etnik Galela Di Kokota Jaya
}

\author{
Dolfina Galela \\ dolfinagalela@gmail.com \\ Djeinnie Imbang \\ Christian G. Ranuntu \\ Pascasarjana \\ Universitas Sam Ratulangi
}

\begin{abstract}
Language and culture have a very close relationship and can not be separated. Indonesia has a variety of very interesting customs, as well as ethnic Galela in Kokota Jaya, North Halmahera in North Maluku province has a variety diariskan customs of the ancestors. One was at the event to woo the girl who is a manifestation of cultural values in the society. In the event there is a form to woo this girl lingual and lexical meaning phrases that have cultural significance. There is also the cultural meanings of verbal and nonverbal expression. This research may be necessary for people to know clearly the meaning of expressions of both verbal and nonverbal ceremonial woo the girl. This study aims to identify and analyze the forms of expression of cultural meanings contained in verbal and nonverbal expression on her proposed marriage ceremony in Kokota Jaya ethnic Galela.
\end{abstract}

Based on the results and discussion can be concluded that there is a form limgual and lexical meaning in the ceremony there was to woo the girl. And there is a meaningful verbal and nonverbal expressions of culture in a ceremony to woo the girl. It is recommended that conducted an exhaustive review of her proposed marriage ceremonies. For Galela ethnic communities in Kokota Jaya especially the younger generation is expected to begin to learn and understand the use of regional languages become heritage.

Keywords: Expression, Cultural, and Galela Ethnic

\section{PENDAHULUAN}

Bahasa sudah menjadi alat komunikasi dalam kehidupan sehari - hari. Bahasa sebagai alat komunikasi lisan ataupun tulisan merupakan salah satu unsur penting yang mencerminkan kebudayaan masyarakat pemakainya. Bahasa tidak hanya digunakan 
sebagai alat komunikasi sosial tetapi juga dapat berfungsi sebagai alat pengungkap pikiran dan perasaan yang mencerminkan pandangan hidup atau pola pikir masyarakat. Dengan kata lain, bahasa dapat mengungkapkan pikiran, perasaan, dan nilai - nilai bahasa ketika bahasa itu dipakai dalam berinteraksi dengan sesama dan lingkungan sekitarnya.

Menurut Kridalaksana, (1998) ungkapan bahasa menyimpan kearifan lokal. Ungkapan - ungkapan bahasa, antara lain seperti yang terlihat dalam peribahasa membimbing perilaku masyarakat agar selaras dengan amanat leluhur dan memungkinkan apresiasi dan pemahaman makna dan gagasan budaya yang telah terbina sebagai alat tradisional sejak dahulu.

Pernyataan Sapir yang dikutip Silzer (1990) menyatakan bahwa kandungan setiap budaya dapat terungkap di dalam bahasanya. Demikian pula, pernyataan Nababan via Silzer (1984) bahwa untuk mengerti suatu kebudayaan secara mendalam kuncinya adalah bahasa. Dalam adat etnik Galela khususnya yang berkaitan dengan adat upacara peminangan di dalamnya ada kebudayaan masyarakat, juga terdapat suatu kerja sama yang baik antarsesama anggota masyarakat etnik Galela. Pemakaian bahasa etnik Galela digunakan secara aktif dalam berkomunikasi pada saat upacara adat peminangan. sehingga merupakan objek studi linguistik yang sangat menarik untuk dikaji. Dengan demikian, penelitian terhadap upacara peminangan merupakan suatu upaya pemahaman terhadap kebudayaan masyarakat etnik Galela melalui "jendela” bahasa.

Budaya adalah pikiran, akal budi, yang di dalamnya termasuk adat istiadat, (Sugono, 2005:169). Dengan demikian, budaya dapat diartikan sebagai sesuatu yang dihasilkan dari pikiran atau pemikiran. Takkala ada ahli menyebutkan bahasa dan pemikiran memiliki hubungan timbal-balik dapat dipahami bahwa pikiran di sini dimaksudkan sebagai sebuah perwujudan kebudayaan. Budaya adalah seluruh sistem gagasan dan rasa, tindakan, serta karya yang dihasilkan manusia dalam kehidupan bermasyarakat (Keontjaraningrat, 2011:72).

Kokota Jaya adalah salah satu desa yang berada di Maluku utara, tepatnya di Kabupaten Halmahera Utara Propinsi Maluku utara. Etnik ini tersebar di 2 kecamatan, yaitu kecamatan Tobelo utara dan kecamatan Tobelo Selatan. Penutur asli etnik Galela merupakan kelompok etnik yang mendiami wilayah Halmahera. Dan adat istiadat yang sudah tertanam sejak kecil tetap dihayati dan di hargai dalam kehidupan sehari - hari, terutama menjalani upacara ritual. 
Budaya masyarakatEtnik Galela merupakan pancaran ketulusan jiwa dan semangat mensyukuri akan karunia Tuhan Yang Maha Kuasa terhadap tanah persadanya. Ini terungkapsetiap upacara seremonial adat maupun upacara-upacara sakral.Pemahaman ini disebut $O$ Guru'mini Ma'oa Awi'ngale yang artinya Yang Kuasa Mengilhami.Budaya merupakan hal yang tidak pernah lepas dari daerah Maluku Utara, daerah disini merupakan daerah yang benar-benar menghargai budaya dan tidak pernah lepas dengan budaya. Pernyataan diatas dapat diperjelas oleh pendapat Titus, Smith dan Nolan (1984), seperti pula dalam Concon via Mustansyir, (1988). Dikatakan bahwa fungsi serimonial merupakan fungsi komunikasi yang bersifat ritual.

Peneliti memilih desa Kokota Jaya yang di dalamnya etnik Galela merupakan etnik yang paling menghargai adat-istiadat terutama pada upacara peminangan gadis. Alasan peneliti memilih upacara adat meminang gadis sebagai objek penelitian karena, peneliti tertarik untuk mengetahui lebih dalam tentang adanya tuturan-tuturan yang disampaikan oleh pihak perempuan dan pihak laki-laki, yang punya kaitannya juga dengan nilai-nilai budaya yang disampaikan. Sehingga peneliti ingin mengenali atau mengetahui apa makna dari tuturan-tuturan tersebut dalam peminangan. Peneliti juga terlibat langsung sehingga ada pengalaman empiris, maka perlu didokumentasikan agar upacara meminang gadis etnik Galela tetap ada dan tetap terjaga secara tutun-temurun.

Dalam upacara peminangan gadis termasuk hal yang lazim dialami oleh kedua calon mempelai dalam etnik Galela disebut goduru (mempelai laki-laki) dan ngongare (mempelai wanita). Perlu dijelaskan bahwa upacara peminangan dalam etnik Galela disebut pomadunia merupakan tahap awal dalam peminangan gadis menurut adat masyarakat Kokota Jaya.

Penelitian ini merupakan penelitian yang mengkaitkan budaya dari sudut pandang linguistik antropologi. Sejauh pengamatan yang dilakukan melalui penelusuran pustaka, belum ada penelitian serupa oleh para peneliti terdahulu.

\section{Perumusan Masalah}

Berdasarkan latar belakang pemikiran diatas, maka yang akan menjadi masalah dalam penelitian ini, yaitu :

1. Apa saja bentuk (lingual) dan makna (leksikal) ungkapan dalam upacara meminang gadis etnik Galela di Kokota Jaya? 
2. Apa saja makna budaya ungkapan verbal dan nonverbal dalam upacara meminang gadis etnik Galela di Kokota Jaya?

\section{Tujuan Menelitian}

Berdasarkan permasalahan yang dilakukan, maka tujuan penelitian ini sebagai berikut:

1. Mengidentifikasi dan mengklasifikasi bentuk (lingual) dan makna (leksikal) ungkapan dalam upacara meminang gadis etnik Galela di Kokota Jaya.

2. Menganalisis makna budaya ungkapan verbal dan nonverbal dalam upacara meminang gadis etnik Galela di Kokota Jaya.

\section{Manfaat Penelitian}

1. Manfaat Teoretis

Secara teoretis penelitian ini memberikan beberapa manfaat yaitu sebagai berikut:

a. Hasil penelitian ini dapat melengkapi pustaka kelinguistikan yang bercorak linguistik Indonesia, khususnya yang berkaitan dengan Ungkapan Bermakna Budaya, etnik Galela di Kokota Jaya Halmahera.

b. Hasil Penelitian ini untuk memperkuat teori Linguistik Antropologi dalam menentukan dan menganalisis makna budaya.

2. Manfaat Praktis

Manfaat penelitian ini secara praktis yakni sebagai berikut:

a. Hasil penelitian ini bermanfaat bagi masyarakat Maluku Utara, khususnya etnik Galela di Kokota Jaya, dalam rangka pelestarian budaya daerah melalui pendokumentasian corak keanekaragaman aset budaya nasional.

b. Selain itu, penelitian ini bermanfaat bagi generasi penerus, khususnya pewaris budaya etnik Galela untuk memahami nilai-nilai budaya yang tersirat dalam penggunaan ungkapan dan bahasa ritual pada upacara peminangan.

\section{Tinjauan Pustaka}

Terdapat penelitian tentang ungkapan bermakna budaya yang memiliki hubungan dengan penelitian ini yakni:

Kawatu (2003) meneliti tentang pemakaian budaya dalam upacara meminang gadis menurut cara etnik pamona di Palu. Penelitian ini bertujuan mengidentifikasi dan mengklasifikasi ungkapan-ungkapan bahasa adat pamona dan mendeskripsikan perilakuperilaku nonverbal dalam kesatuan yang tidak terpisahkan dengan perilaku verbalnya. Data 
yang dikumpulkan mengunakan teknik observasi dan wawancara terbuka. Kawatu mengunakan teori oleh Concon via Mustansyiir, (1988). Terdapat fungsi seremonial merupakan fungsi komunikasi yang bersifat ritual. Kawatu mengkaji untuk mengetahui pemakaian dan variasi bahasa yang dipakai para partisipan dalam upacara adat meminang gadis menurut etnik pamona dan perilaku verbal dan non verbal sedangkan penelitian ini mengkaji makna budaya dan menggunakan kajian linguistik antropologi.Muhamad (2007) melakukan penelitian tentang ungkapan tarian togal di Pulau Makian. Ia mendeskripsikan dan mengidentifikasi serta menguraikan bagaimana ungkapan-ungkapan dalam tarian togal mencerminkan pola pikir masyarakat Makian Pulau. Muhamad menggunakan konsep Hymes (1970). Dari hasil penelitian ditunjukkan bahwa ungkapan bermakna budaya yang digunakan masyarakat Pulau Makian sebagian besar terdiri dari frase, klausa, dan kalimat serta ungkapan-ungkapan tersebut merupakan rangkuman pola pikir mereka tentang nilainilai kehidupan. Hal yang membedakan penelitiannya dengan peneliti yakni muhamad kajiannya yaitu kajian etnolinguistik sedangkan peneliti menggunakan kajian linguistik antropologi. Walaupun keduanya meneliti tentang makna budaya. Selain itu terdapat perbedaan juga pada objek penelitian. Wattimury (1992) meneliti tentang bahasa Galela di kabupaten Halmahera Utara, penelitian ini merupakan kumpulan tulisan bahasa Galela, struktur gramatika bahasa Galela dan pembuatan kamus sederhana bahasa Galela. Dari proses dan penelitian ini, menunjukan bahwa fonem bahasa Galela secara umum terdapat kemiripan dengan fonem bahasa Indonesia, perbedaan terletak pada fonem $/ d /$ yang diucapkan dengan lidah kena gigi atas dan melekat pada langit-langit sampai gusi yang dibelakang gigi atas, sedangkan diftong bahasa Galela (Halmahera Utara) terdapat pada posisi akhir, misalnya moi 'satu', mia 'kera', hai 'lipan', dan sebagainya, sedangkan fonem /o/ dipakai untuk menunjukan benda, misalnya: o ake 'air'. Wattimury tidak menganalisis makna budaya sedangkan penelitian ini akan menganalisis dari ungkapan bermakna budaya.

\section{Kerangka Teoretis}

Kerlinger (1973) mengemukakan teori merupakan seperangkat konsep, definisi dan proposisi yang berfungsi untuk melihat fenomena secara sistematik, melalui spesifikasi hubungan antara variabel sehingga dapat berguna untuk menjelaskan dan meramalkan fenomena. Kerangka teoritis yang digunakan dalam penelitian ini ialah gabungan pendapat para ahli tentang linguistik antropologi, ungkapan dan makna budaya. 


\section{Linguistik Antropologi}

Linguistik antropologi merupakan salah satu cabang linguistik yang meneliti tentang hubungan bahasa dan pola kebudayaan. Cabang ilmu ini melihat hubungan antara bahasa dan kebudayaan. Bahasa merupakan alat utama satu-satunya untuk memasuki kehidupan kelompok masyarakat budaya tertentu (Parera, 1982).

Foley (1997:3) mengemukakan bahwa linguistik antropologi merupakan bagian dari linguistik yang menaruh perhatian pada bahasa dalam konteks sosial dan budaya, dan juga peran bahasa dalam menempa dan memelihara praktik budaya dan struktur sosial. Pendekatan linguistik antropologi mencoba melihat apa yang pengguna bahasa maksudkan ketika dia berbicara. Menurut hipotesis Sapir-Whorf (1921), bahasa tidak hanya mencerminkan budaya tapi juga mempengaruhi budaya atau didalam bahasa terkandung makna-makna budaya yang mencakup berbagai aspek kehidupan.

2. Ungkapan

Secara etimologi ungkapan berasal dari kata ungkap (verba) yang berarti buka, diungkap. Ketika mendapat sufiks-an maka maknanya berubah menjadi, apa-apa saja yang diungkapkan, kelompok kata atau gabungan kata yang menyatakan makna khusus (makna unsur-unsur seringkali menjadi kabur) Sugono, 2015. Bagian yang lain menurut Kridalaksana (1982: 21) ungkapan adalah kontruksi satuan bahasa yang maknanya melebihi makna leksikal dan bahkan makna gramatikal yang terkandung dalam bahasa tersebut. Marnita dan Oktavianus (2008 : 220) mengemukakan bahwa ungkapan merupakan sarana yang dapat mempertajam intelektual, karena ungkapan menggunakan kata-kata kias yang maknanya tidak langsung dan hanya bisa dimengerti dengan cara memahami alam dan budaya lokal. Hal ini lebih dipertegas lagi oleh keraf (2007 : 109) bahwa ungkapan adalah pola - pola struktural yang menyimpang dari kaidah - kaidah bahasa yang umum, biasanya membentuk frasa, sedangkan artinya tidak dapat diterangkan secara logis atau secara gramatikal, dengan bertumpu pada makna dan pada kata - kata yang membentuknya. De Saussure dalam Chaer (2007) setiap tanda linguistik terdiri dari unsur signifiant (bentuk) dan unsur signifie (konsep,makna).Dalam kaitan dengan penelitian ini, peneliti mengacu pada pendapat Sugono (2015) dan Saussure dalam Chaer (2007), untuk mendeskripsikan bentuk (lingual) dan makna (leksikal). Dalam upacara meminang gadis, yaitu apa saja yang diungkapkan baik bentuk kata, frase, kalimat maupun 
wacana singat. Demikian pula, dilengkapi dengan pendapat Kridalaksana (1982), Keraf (2007), dan Oktovianus (2008).

\section{Ungkapan Verbal}

Ungkapan yang dilakukan dengan menggunakan kata-kata disebut ungkapan verbal atau bahasa verbal. Bahasa verbal adalah bahasa formal baik lisan maupun tulisan yang diakui dan digunakan untuk menyampaikan semua yang dirasakan,dipikirkan, dan diketahui kepada orang lain. Hal ini sejalan dengan Mulyana (2005) yang menyatakan bahwa simbol atau pesan verbal adalah semua jenis simbol yang menggunakan satu kata atau lebih. Menurutnya bahasa dapat juga dianggap sebagai sistem kode verbal. Dari penjelasan di atas dapat disimpulkan bahwa bahasa dapat diartikan sebagai seperangkat simbol dengan aturan-aturan yang digunakan untuk mengkomunikasikan simbol-simbol tersebut agar dapat dipahami oleh suatu komunikasi tertentu.

Selanjutnya, ungkapa tradisional (verbal) menurut Yuzar (2005) terbagi menjadi 6 jenis yaitu:

a. Kata-kata adat: berisikan ketentuan-ketentuan yang harus dipahami oleh pemangku-pemangku adat yang disampaikan dalam bentuk kalimat lengkap.

b. Pepatah: ungkapan yang berisikan anjuran, karangan, kritikan dan sindiran yang disampaikan dalam satu kalimat pendek.

c. Perumpamaan: mengibaratkan langsung antara tingkah laku atau keadaan manusia dengan binatang, tumbuhan, alam sekitar yang diungkapkan dalam suatu kalimat lengkap dan didahului dengan kata-kata: bagai, bak, sebagai dan bagaikan.

d. Tamsil (ibarat): ungkapan berupa perumpamaan yangdilengkapi dengan keterangan dan diungkapkan dalam kalimat tunggal yang digabungkan menjadi satu kalimat.

e. Metafora: ungkapan yang terdiri atas satu kelompok yang isinya melukiskan sifat, tingkah laku dan keadaan manusia dengan membandingkannya dengan sifat alam, tumbuhan dan binatang.

f. Pameo: kelompok kata atau kalimat yang mengandung ejekan atau dorongan dan semangat.

\section{Ungkapan Nonverbal}

Ungkapan yang dilakukan tanpa penggunaan kata-kata disebut ungkapan nonverbal. Salah satu cara untuk berkomunikasi secara nonverbal ialah dengan menggunakan isyarat atau gerak tubuh. Secara teoritis komunikasi verbal dan nonverbal 
dapat dipisahkan, namun dalam kenyataannya kedua jenis komunikasi ini saling melengkapi dalam komunikasi yang kita lakukan sehari-hari. Pesan-pesan nonverbal menurut Rakhmat (1994) sebagai berikut:

a. Pesan Kinestik. Yaitu pesan nonverbal yang menggunakan gerakan tubuh yang berarti, terdiri dari tiga komponen utama yakni:

1. Pesan faisal menggunakan air muka untuk menyampaikan makna tertentu.

2. Pesan gestural menunjukan gerakan sebagian anggota tubuh seperti mata dan tangan untuk mengkomunikasikan berbagai makna.

3. Pesan postural berkenaan dengan keseluruhan anggota tubuh, makna yang dapat disampaikan adalah: a) Immediacy yaitu ungkapan kesukaan dan ketidaksukaan terhadap induvidu lain; b) Power menggunakan status yang tinggi pada diri komunikator; c) Responsiveness, induvidu dapat bereaksi secara emosional pada lingkungan secara positif dan negatif.

b. Pesan Prosemik. Disampaikan melalui pengaturan jarak dan ruang. Umumnya dengan mengantur jarak kita dalam mengungkapkan keakraban kita dengan orang lain.

c. Pesan Artifaktual. Diungkapkan melalui penampilan tubuh, pakaian, dan kosmetik.

d. Pesan Paralinguistik. Pesan nonverbal yang berhubungan dengan cara mengucapkan pesan verbal. Satu pesan verbal yang sama dapat menyampaikan arti yang berbeda bila diucapkan secara berbeda.

e. Pesan Sentuhan dan bau-bauan. Alat penerima sentuhan adalah kulit, yang mampu menerima dan membedakan emosi yang disampaikan melalui sentuhan. Sementara bau-bauan, terutama yang menyenangkan telah berabad-abad digunakan orang, juga untuk menyampaikan pesan yang menandai wilayah mereka,mengidentifikasi keadaan emosional, pencitraan dan menarik lawan jenis.

Menurut Poter dan Samavar (dalam Rakhmat,1994) ciri-ciri pesan nonverbal dapat dilihat dari cara penyampaiannya yaitu dengan menggunakan isyarat (gesture), gerakgerik (movement), postur, parabahasa, kinesik, sentuhan, penampilan fisik, ruang, jarak, waktu, produk konsumen, dan artefak.

Selain apa yang telah disebutka diatas, berbicara mengenai ungkapan nonverbal bukan hanya dalam bentuk gerak isyarat melainkan bentuk benda atau material yang disebut dengan makanan rakyat atau makanan adat. Suatu bahan itu bisa dimakan atau 
tidak, sangat ditentukan oleh kebudayaan dari setiap suku bangsa atau agama masingmasing. Hal ini sejalan dengan pendapat Foster dan Anderson (1978, dalam Danandjaja, 1995) yang menyatakan bahwa kebudayaan adalah yang menentukan sesuatu itu merupakan makanan atau bukan. Makanan selain penting untuk kehidupan biologis juga penting dalam hubungan sosial.

\section{Makna Budaya}

Menurut Nababan dalam Syafyahya (2010), bahasa sebagai suatu sistem komunikasi merupakan suatu bagian atau subsistem dari sistem kebudayaan, namun, merupakan inti dan terpenting dari kebudayaan. Bahasa terlibat dalam semua aspek kebudayaan, paling minim dengan cara mempunyai nama atau istilah bagi unsur-unsur dari semua aspek kebudayaan. Hal yang lebih penting dari itu, kebudayaan manusia tidak akan dapat terjadi tanpa bahasa karena bahasa merupakan faktor yang memungkinkan terbentuknya kebudayaan. Hal ini bisa dipahami saat manusia membayangkan sejenak bagaimana bisa mengembangkan unsur-unsur kebudayaan seperti pakaian, rumah, lembaga pemerintahan, lembaga perkawinan dan hukum tanpa adanya bahasa.

Demikian pula, bahasa dari sudut pandang kebudayaan dikaji dalam linguistik antropologi untuk menemukan makna di balik penggunaan bahasa itu sendiri.

Sistem makna budaya menurut D'Andarde (1784) terdiri dari empat sistem yakni:

1. Representasional, yaitu makna-makna mewakili dunia secara keseluruhan.

2. Constructive, yaitu makna-makna mengkreasikan kesatuan wujud atau kebudayaan. Makna budaya ungkapan dapat dianalisis dalam lingkup ungkapan verbal dan nonverbal.

3. Directive, yaitu makna-makna menjadi pedoman seseorang dalam melakukan hal tertentu.

4. Evocation, yaitu makna-makna sebagi pembangkit perasan-perasaan tertentu.

Dari teori-teori yang dikemukakan di atas untuk menjawab perumusan masalah kedua yaitu makna budaya dari ungkapan-ungkapan verbal dan nonverbal yang ada dalam upacara meminang gadis, peneliti menggunakan teori Yuzar (2005), Rakhmat (1994), dan D'Andarde (1984). 


\section{METODOLOGI PENELITIAN}

Metode yang digunakan dalam penelitian ini ialah metode kualitatif yang bersifat deskriptif yakni metode yang menggambarkan segala sesuatu secara apa adanya, artinya data yang dikumpulkan sesuai dengan kenyataan yang terdapat pada objek penelitian.

\section{Lokasi dan Waktu Penelitian}

Penelitian ini dilakukan di sebuah desa di Kota Tobelo Utara yaitu desa Kokota Jaya. Penelitian ini pada tahap awal melakukan observasi pada hari sabtu tanggal 10 Januari dan pada tahap kedua penelitian ini selama 3 bulan, peneliti memilih desa Kokota Jaya karena desa ini merupakan desa adat tertua di Kota Tobelo Utara. Desa Kokota Jaya terletak pada sebuah bukit di pegunungan Mede, dan berjarak 10km dari pusat Kota Tobelo. Berikut ini merupakan penjelasan lebih lanjut tentang desa Kokota Jaya yang harus diketahui berhubungan dengan pemaknaan budaya dalam penelitian ini:

1. Latar belakang sejarah

a. Pra Pemekaran

Desa Kokota Jaya pada tempo dulu adalah wilayah kesatuan masyarakat yang dimulai dengan nama koru yang dipimping oleh seorang tua adat yang biasa disebut Kimalaha (Kepala Kampong). Desa Kokota Jaya dulu masih menyatu dengan Desa Ruko berdiri sekitar tahun 1932 yang dipimpin oleh seorang tua adat pertama bernama Dowo Tidore, nama desa Ruiko diambil dari nama binatang melata yaitu Kepiting dalama bahasa Tobelo dinamakan Korusedangkan dalam bahasa Galela disebut Kohoruyang banyak dijumpai di sekitar wilahyah Ruko. Desa Ruko merupakan salah satu Desa Tua yang berada disebelah Utara Kabupaten Halmahera Utara sebelum tahun 1950 Desa Ruko sangat luas yang mencakup batas wilayahnya sebelah selatan dengan Desa Popilo sedangkan disebelah Utara berbatasan dengan Desa Luari sedangkan disebelah Barat dan Timur berbatasan dengan Pegunungan dan Laut.

\section{b. Pasca Pemekaran}

Seiring dengan semangat otonomisasi Desa dan dinamika masyarakat yang menginginkan percepatan pembangunan maka pada tahun 2005 Desa Ruko dimekarkan menjadi Dua Desa yakni Desa Ruko (Induk) dan Kokota Jaya. Nama Kokota Jaya diambil dari sebuah nama ataupun sebutan pada wilayah yang ada di Desa Kokota Jaya dan tempat itu diyakini merupakan sebuah tempat dimana pada PD II pasukan Portugis mendirikan 
benteng di tempat itu. Awalnya ada berbagai pikiran dan pendapat yang muncul dimasyarakat tersebut terkait nama Desa yang baru dimekarkan ini tapi dari pertimbangan sejarah itulah maka muncullah dalam pikirang orang tua di Desa Kokota Jaya untuk menamakan Desa tersebut dengan Kokota Jaya.

\section{Pemilihan Informan}

Menurut Nida (1946:190), syarat - syarat informan yang baik adalah : memiliki intelegensi yang baik dalam arti mempunyai kematangan mental, memiliki kepribadian yang komunikatif dan pengetahuan yang cukup. Selanjutnya menurut Spradley (1997:68) ada lima persyaratan minimal untuk menjadi informan baik yakni :

a. Enkulturasi penuh

b. Keterlibatan langsung

c. Suasana budaya yang tidak dikenal

d. Waktu yang cukup, dan

e. Non analitik

Berdasarkan pertimbangan pernyataan di atas maka peneliti menetapkan informan yang terdiri dari 5 (lima) orang, dengan alasan bahwa pelaksanaan adat peminangan melibatkan banyak partisipan. Masing - masing informan memiliki peran yang berbeda dalam tugas dan jabatan yang dimiliki yaitu seorang kepala Desa, Ketua adat, Anggota Dewan adat, tokoh wanita dan Tokoh Masyarakat, kesemuannya memberikan informasi sesuai keterlibatan mereka dalam pelaksanaan adat peminangan.

\section{Metode Pengumpulan Data}

Data dikumpulkan dengan menggunakan data primer dan data sekunder. Data primer dalam penelitian ini diperoleh melalui data rekaman upacara adat meminang gadis yang telah terdokumentasi. Selanjutnya penelitian melakukan wawancara langsung kepada informan yang berkompeten guna mendapatkan makna budaya. Teknik wawancara dilakukan dengan tahap-tahapan dalam bentuk deskriptif seperti yang dikemukakan oleh Spradley (1997).

1. Grand Tourquestion, Pertanyaan ini bersifat mendorong informan untuk terus menerus berbicara Contoh: Dapatkah Bapak menceritakan bagaimana cara meminang gadis? 
2. Mini Tour question, Pertanyaan untuk menyelidiki berbagai aspek pengalaman yang lebih rinci. Contoh: Dapatkah Bapak jelaskan benda apa saja yang harus disiapkan dan dibawah pihak penerima gadis ketika berlangsung upacara meminang gadis ?

3. Experience question, pertanyaan yang menghendaki informasi budaya atau berupa pengalaman pribadi atau orang lain. Contohnya : dapatkah Bapak/Ibu menceritakan pengalaman ketika melaksanakan tugas sebagai pelaksana penyerahan bahanbahan untuk upacara adat peminangan ?

Setelah data primer terkumpulkan, peneliti melakukan kajian pusta untuk menelusuri penelitian-penelitian yang ada kaitannya dengan bidang ini sebagai data sekunder. Data sekunder dalam penelitian ini ialah data tertulis tentang upacara adat meminang gadis.

\section{Teknik Analisis Data}

Analisis data mulai dilakukan bersamaan dengan pengumpulan data melalui wawancara langsung. Saat melakukan wawancara, peneliti mulai menganalisis jawaban yang diberikan informan. Bila jawaban yang diberikan kurang memuaskan maka peneliti memberikan pertanyaan lagi untuk memperoleh data yang cukup. Peneliti menyimak konsep Sugiyono (2009) menyatakan analisis bahasa meliputi kegiatan reduksi kata, penyajian data dan kesimpulan. Reduksi kata berarti merangkum, memilih hal-hal yang pokok, memfokuskan pada hal-hal yang penting, dicari tema sehingga data yang telah direduksi akan memberi gambaran yang jelas dan mempermudah peneliti untuk melakukan pengumpulan data selanjutnya. Reduksi kata sangat diperlukan karena data yang didapatkan di lapangan harus disesuaikan dengan tujuan penelitian.

Penyajian data dilakukan dengan tujuan agar data yang didapat akan diorganisasikan, disusun sehingga akan semakin mudah dipahami. Setelah mereduksi dan menyajikan data maka langkah selanjutnya melakukan verifikasi data. Verifikasi data ini dilakukan selama penilitian berlangsung.

Pemaknaan budaya dari ungkapan-ungkapan dalam upacara meminang gadis digunakan teori Yuzar (2005), khususnya untuk menganalisis ungkapan verbal, sedangkan ungkapan nonverbalnya mengacu pada teori Rakhmat (1994). Mencari makna budaya dari ungkapan verbal dan nonverbal dalam penelitian ini digunakan teori sistem makna budaya oleh D’Andarde (1984). Foley (1997) yang dinyatakan bahwa linguistik antropologi 
memandang dan mengkaji bahasa dari sudut pandang bahasa dan budaya untuk menemukan makna dibalik pemakainya.

\section{Pembahasan}

Dengan mengacu pada konsep Sugono (2015) yang berpendapat apa saja yang diungkapkan baik bentuk kata, frasa, kalimat maupun wacana singkat. ditemukan ada beberapa bentuk ungkapan, kata, frasa, klausa dan wacana singkat dalam upacara meminang gadis yang disampaikan oleh Kap dan Kal yang berisi salam, menghormati dan menghargai antarasesama dalam upacara adat meminang gadis. Dikaitkan dengan teoriteori linguistik dan antropologi yang terdapat pada kerangka teoretis.

1. Bentuk (lingual) dan makna (leksikal) Ungkapan yang ada dalam upacara Meminang Gadis

Hasil dari penelitian ini terdapat bentuk kata, frasa, klausa dan wacana singkat seperti yang dijelaskan Sugono (2015). Bentuk-bentuk tersebut antara lain:

a. Bentuk kata

\section{1) Pomadunia}

Poma 'Berangkat'

Dunia 'Meminang'

'Berangkat meminang'

Kata Pomadunia berasal dari bentuk dasar poma yang secara semantik 'berangkat' (verba) dan mengalami proses derivasi sehingga menjadi Pomadunia yang secara semantik bermakna 'meminang' (nomina). Kata pomadunia merupakan jenis makna luas (extended meaning) yaitu makna yang terkandung pada sebuah kata lebih luas dari yang diperkirakan.

2) Kabilano

Kabi 'tempat'

Lano 'menaruh'

'Tempat menaruh'

Kata kabilano berasal dari bentuk dasar kabi yang berarti 'tempat' (verba) dan mengalami proses derivasi sehingga menjadi kabilano 'tempat menaruh' kata kabilano secara semantik bermakna 'tempat pinang' merupakan jenis makna luas.

\section{3) Omokuru}

Omo 'makan' 
Kuru 'pinang'

'Makan pinang'

Kata Omokuru berasal dari bentuk dasar omo yang berarti 'makan' (verba) dan mengalami proses derivasi sehingga menjadi omokuru 'pinang' (nomina). Kata omokuru yaitu makna yang terkandung pada sebuah kata lebih luas dari yang diperkirakan.

\section{4) Obido}

Bido 'sirih'

'Sirih'

Kata obido berasal dari bentuk dasar bido 'sirih' (verba) dan mengalami proses derivasi sehingga menjadi obido 'sirih' yaitu makna yang terkandung pada sebuah kata.

\section{5) Odofahe}

Dofahe 'kapur'

'Kapur'

Kata odofahe berasal dari benruk dasar dofahe yang berarti 'kapur' (verba) dan mengalami proses derivasi sehingga menjadi odofahe 'kapur' (nomina). Kata odofahe yaitu makna yang terkandung pada sebuah kata dan tidak berubah artinya.

\section{6) Otabako}

Tabako 'rokok'

'Rokok'

Kata otabako berasal dari bentuk dasar tabako 'rokok' (verba) dan mengalami proses derivasi sehingga menjadi otabako 'Rokok' yaitu makna yang terkandung pada sebuah kata dan tidak berubah artinya.

\section{7) Opipi}

Pipi 'uang'

'Uang'

Kata opipi berasal dari bentuk dasar pipi 'uang' (verba) dan mengalami proses derivasi sehingga menjadi opipi 'uang' (nomina). Kata opipi yaitu makna yang terkandung pada sebuah kata dan tidak berubah artinya.

b. Bentuk frasa

1) Suba jou

Suba 'sembah'

Jou 'Tuhan' 
'Sembah Tuhan'

Ungkapan ini berbentuk frasa verba dan berjenis koordinatif, karena merupakan frasa yang pembentuknya terdiri dari dua komponen yakni verba suba 'sembah' dan verba jou 'Tuhan'. Frasa ini mengandung makna kognitif atau makna denotatif yang merupakan makna sebenarnya dan bukan perumpamaan.

2) Uru mabobelenga

Uru 'mulut'
Mabobelenga 'pembuka
'Pembuka mulut'

Ungkapan ini berbentuk frasa verba dan berjenis koordinatif, karena merupakan frasa yang pembentuknya terdiri dari dua komponen yakni verba uru 'mulut dan verba mabobelenga 'pembuka'. Frasa ini mengandung makna kognitif atau makna denotatif yang merupakan makna sebenarnya dan bukan perumpamaan.

1) Ongeko marari

Ongeko 'jalan'

Marari 'pembuka'

'Pembuka jalan'

Ungkapan ini berbentuk frasa verba dan berjenis koordinatif, karena merupakan frasa yang pembentuknya terdiri dari dua komponen yakni verba ongeko 'jalan' dan verba marari 'pembuka'. Frasa ini mengandung makna kognitif atau makna denotatif yang merupakan makna sebenarnya dan bukan perumpamaan.

2) Dola bololo

Dola 'syair'

Bololo ' berbalas'

'Berbalas syair'

Ungkapan ini berbentuk frasa verba dan berjenis koordinatif, karena merupakan frasa yang pembentuknya terdiri dari dua komponen yakni verba dola 'syair' dan verba bololo ' berbalas'. Frasa ini mengandung makna kognitif atau makna denotatif yang merupakan makna sebenarnya dan bukan perumpamaan.

Bentuk frasa, dan klausa juga tampak pada ungkapan-ungkapan yang ada dalam tahapan berikut.

a. Tahap pertama ( Pelaksanaan ) 
1)Ungkapan salam (bentuk frasa)

TR : Hino... Wosa no

Datang, Masuk kemari

$$
\text { 'Mari, Silahkan Masuk' }
$$

Ungkapan ini berbentuk frasa verba dan berjenis koordinatif, karena merupakan frasa yang komponen pembentuknya terdiri dua komponen yakni verba hino 'datang' dan wosa 'masuk' yang dihubungkan oleh konjungsi koorninatif tunggal no 'kemari'. Makna yang terkandung dalam frasa ini merupakan makna kognitif atau makna denotatif yaitu makna sebenarnya dan bukan perumpamaan.

2) Ungkapan menghormati (bentuk klausa)

RkL : Jojo... Ka Mi Gila gilano

Baik, kita mau masuk

$$
\text { 'Iya, kami akan masuk' }
$$

Ungkapan ini berbentuk klausa bebas. Berdasarkan kategori unsur segmental maka klausa ini dikategorikan sebagai klausa verbal (transitif) yaitu klausa yang predikatnya berupa verba transitif. Klausa ini mengandung makna idiomatik.

3) Ungkapan mempersilakan duduk (bentuk klausa)

TR : Ni matameka kagena.

Kalian, duduklah disitu

: 'Silahkan duduk ditempat yang telah disediakan'

Ungkapan ini berbentuk klausa bebas karena memilili struktur yang lengkap. Makna yang terkandung dalam klausa ini adalah makna emotif yaitu makna yang melibatkan perasaan ke arah positif.

4) Ungkapan menghargai (bentuk klausa)

$\mathrm{RkL} \quad$ : jojo... Mi matame ka.

Baik, kita akan duduk

: 'Iya, Kami akan duduk'

Ungkapan ini berbentuk klausa bebas karena memilili struktur yang lengkap. Makna yang terkandung dalam klausa ini adalah makna emotif yaitu makna yang melibatkan perasaan ke arah positif.

b. Tahap kedua peminangan resmi 
Ungkapan yang disampaikan oleh pihak perempuan dan pihak lelaki dalam bentuk wacana seperti di bawah ini:

1) Kap : Ai Dodihimo, Riadegia nongoru, awa bira yang tini hormati Orang tua, kakak adik, saudara saudari yang di hormati lebih khusus pihak yanau yang tini hormati, setelah tini na nano ai tahu lebih khusus pihak lelaki yang di hormati, setelahdi rumah, nibola naga de dodoa, mungkin naga, paro, so ni so tutu hino, datang ada apa, mungkin ada, angin, jadi terdampar kesini,

so nako naga de nia maksud tanu no masi bicaraka.

jadi kalau ada maksud tolong disampaikan.

'Para orang tua, kakak dan adik serta saudara-saudari, yang kami hormati, terlebih khusus pihak lelaki yang kami hormati. Setelah kami amati kalian ada di tempat ini, kalian datang dengan maksud dan mungkin juga karena badai sehingga dapat singgah istirahat di tempat ini. Jika ada maksud dan tujuan silahkan di sampaikan'

2) KaL: Ai Dodihimo, Riadeogia nongoru, awa bira yang hormat Orang tua, kakak adik, saudara saudari yang hormati.

khusus tahu ma duhutu tini hormati, suba Jou. khusus rumah tuan di hormati, sembah Tuhan.

Tarima kase dala-dala, atas waktu deo kesempatan hike.

Terima kasih banyak-banyak, atas waktu dan kesempatan berikan.

Waktu to bola nia tahu no na ga, ai dodagi maraba ka mungkin,

Saat datang jumah dalam mungkin,

mote, gahi, nia adat, nagadeai salah tanu no si maaf.

ikut, aturan, adat, salah tolong maaf.

Madopa dema gena kangano na ga so o bicara ka ai maksud.

Selanjutnya itu tadi bicara maksud. 
'Para orang tua serta kakak dan adik, yang kami hormati, khususnya tuan rumah yang kami hormati, Puji Tuhan. Terima kasih banyak atas waktu juga kesempatan yang telah diberikan, ketika kami datang di rumah ini, mungkin saja ada tingkah laku dan cara kami yang tidak ikuti aturan adat. Jika kami salah mohon dimaafkan. Kami punya maksud tersendiri untuk datang ke tempat ini'

1) Kap: Jojo.. nako ko magena, mana no si ngasu, no temo dika. Baiklah... kalau begitu, ini tahuu, bilang saja.

Okia no maksud deo tujuan no bola ai tahu ka? Apa maksud dengan tujuan datang rumah ku?'

'katakan saja apa yang menjadi maksud atau tujuan kalian datang kesini'

2) KaL: Ai Dodihimo, riadeogia nongoru, awa bira. Orang tua, kakak adik, saudara saudari.

Owange kangano, toma sininga tahie.

Hari tadi, mengingat lagi.

Kapururuo nanga, ake atau nanga talaga ma toku ka gena,

lalu kami, air atau talaga disitu, ngohi ta nanano gena ma namo dodara lori. aku melihat itu burung lori.

Gena $i$ tibo metano, de ngohi tosano, dooha magena ai ngopa? Itu berenang hadapanku, lalu kubertanya, mengapa anakku?

namun muna mo jawabwa. De ami kongo ma girina katura gena. namun dia tidak jawab. airmata menetes itu. ngohi ai giakama gubaliku yo dutu namo lori liho. kita tangan kananku jatuh burung lori pulang.

'Para orang tua serta kakak dan adik. Hari ini kami mengingat/tengok melihat ke danau, kami sementara duduk ditepi danau, dengan tiba-tiba burung air (anak gadis) menuju ke tempat kami, kemudian kami tanya : Hi, burung kenapa ? mungkinkah dia bersedih? dan kemudian meneteskan air mata. Kami berpikir tanda ini baik adanya, karena kami punya anak putra' 
Kagena ngohi sosininga, ai mo make kangano so oras manena ngohi,

Disitu kita ingat, dapat tadi hari ini kita, masi diadoka ngini nia sibua marabaka, gena ai kekurangan de ai more, sudah datang kalian sabuah dalam, itu kurang lebih,

'Mau tidak mau kami harus mencari si gadis itu, terus kami sepakat untuk memanggil keluarga dan pemangku adat untuk kami masuk melamar secara adat. Kemudian dengan semangat kami, kini kami telah berada di rumah keluarga perempuan dengan kekurangan dan kelebihan, kami tidak dapat menceritakan kepada kalian'

Ai Dodihimo, riadeogia nongoru, awa bira.

Orang tua, kakak adik, saudara saudari.

Supaya niise tongohi ai bicara, gena mangale nanga,

Supaya dengar kita bicaraku, itu supaya kami,

ngopa yo sinoto manena gena, tagolo ngohi bicara.

anak dua ini itu, minta kita bicara.

okia deo kia, mangeko idodooha, supaya ngohi to pakisan.

apa dengan apa, jalan seperti, supaya kita permisi.

de ngohi tanako mangale.

Dan kita tahu sebenarnya.

'Para orang tua serta kakak dan adik, kirannya maksud dan tujuan kami yang sudah kami sampaikan untuk kedua anak ini. Untuk itu kami minta bicaralah kiranya hal-hal apa saja yang harus disiapkan untuk jalan mereka supaya kami mengerti dan daoat mengetahuinya'

1) KaP : Nako bisa, sebelum ngomi si ngasu omi mia gogolo dede nginika

kalau bisa, sebelum kami tahu minta pada kalian,

gena poma moku kasi de po ma suyu kasi.

itu pinang dulu merokok dulu.

'Jikalau bisa, sebelum kami sampaikan permintaan kami kepada kalian, bersantailah dengan makan pinang dan merokok terlebih dahulu'

1) KaP: Ngomi mia gogolo gena, hanya ngone nanga adat

kami minta itu, hanya kami punya adat. 
'Permintaan kami tidak ada untuk peminangan anak kami, hanya persyaratan adat saja yang harus dilakukan’

2) KaL:Suba jou karana ngohi toise nakoka, cuma ngohi

Sembah Tuhan Mahakuasa kita dengar tahu, hanya kita

airia nongoru, awa bira, gena upa sidago masahe dasiri

kakak adik, saudara saudari, itu jangan sampai kepala sakit.

Deduba, de o dulali kiaku tahado, ka genalah ngohi ta golo harus ma demo.

salahkan, tuduh dimana taruh, itulah kita mintaharus kata.

Puji Tuhan, kami sudah dengar dan mengetahuinya, hanya kami minta sebut saja kalau bisa. Jangan sampai ia sakit. Karena itu kami meminta harus kalian katakan’

1) KaP : Nako koma gena ongeko maseredi,

Kalau begitu pembuka jalan,

ongihi madagali gena mori butanga (60 Rial), susu ma biji.

tempat pengganti itu puluh enam (60 rial)' susu ibu biji.

Cuma ngomi mia ngopa gena barangwa,

Cuman kami punya anak itu barang,

atau mi masi ija wa gena ngini mia gogolo.

atau jual itu kalian punya minta.

Ngomi hanya miapeto gena i malamo atau maronga,

Kami hanya sebut itu banyak atau namanya,

orugi gena o cala moi (100 rial).

kerugian itu seratus ribu (100 rial).

Gena ngomi tide, wa so

Itu kami angakat,

ngopa ya sinoto manga dodoku yo kahika yo kahino.

anak dua ini tempat kesana kemari. 
'Jikalau begitu, Pembuka jalan, Pengganti tempat, Air susu ibu, Cuma anak kami bukan barang atau kami jual, tapi itu kalian yang meminta, kami hanya mengatakan saja, kerugian itu kami angkat untuk kedua anak yang akan hidup bersama’

2) KaL: Oras manena ngomi mia nako de misi hodaka.

Hari ini kami tahu dan tahu.

Tingini nia bicara kanano manena jadio wange,

Kalian bicara tadi ini jadi hari,

mana ngomi mia aho mia namo lori,

ini kami bawah burung lori,

cuma ngomi golo dede ngini kani mi si daaho.

cuman kami minta kepada kalian bawah.

Supaya ngone paaka nanga adatposi dodogo gena de nanga more.

Supaya kami buat ini adat tambah itu itu senang.

'Saat ini kami sudah tahu sebelumnya jadi sekarang kami akan bawa burung air ini, tapi kami minta kepada kalian supaya kami buat adat kami, untuk kami bersyukur atas kejadian ini'

Ungkapan wacana ini menjelaskan bahwa dalam upacara peminangan gadis etnik Galela yang ada di Kokota Jaya, setiap ungkapan yang disampaikan harus menggunakan bahasa etnik Galela dalam setiap upacara meminang gadis. Dengan alasan karena ini adalah salah satu syarat dalam upacara meminang gadis, dan diharuskan untuk memakai ungkapan etnik Galela. Dalam ungkapan wacana dari kedua belah pihak yaitu Kap dan Kal slalu bergantian atau berbalas ungkapan yang disampaikan pada saat meminang gadis. Kemudian dalam ungkapan wacana ini juga peristiwa-peristiwa yang terjadi sangatlah berkesan dan menggambarkan bahwa etnik Galela memegang teguh adat-istiadat dari dahulu sampai sekarang. Agar tidak hilang dan tetap dijaga sampai turun-temurun. serta dihargai dan dijunjung tinggi oleh generasi-genarasi penerus.

2. Makna Budaya ungkapan verbal dan nonverbal dalam upacara meminang gadis

Ada 6 jenis ungkapan verbal yang tergolong ungkapan tradisional (Yuzar, 2005), dari ungkapan-ungkapan verbal yang telah diperoleh dalam penelitian ini, ditemukan dua jenis berdasarkan teori Yuzar (2005) yakni sebagai berikut: 


\section{Kata-kata adat}

Ungkapan-ungkapan berikut ini tergolong kata-kata adat karena ungkapan ini merupakan ketetapan-ketetapan yang sudah ada dari dulu.

a. Subah jou

'Sembah kepada Tuhan'

b. Hino wosano

'Datang masuk kemari'

c. Ai dodihimo, ria de i gia nongoru, awa deo bira

'Orang tua, kakak dan adik, saudara dan saudari'

d. Jojo ka mi gila-gilano

'Baik, kita mau masuk'

e. Ni matameka kagena

'Kalian, duduklah disitu'

f. Ngeko maseredi

'Pembuka jalan'

g. Uru mabobelenga

'pembuka mulut'

h. Ngihi madagali

'pengganti tempat'

i. Jojo mi matameka

'Baik, kita akan duduk'

2. Pepatah

Pepatah berdasarkan teori Yuzar (2005) salah satunya berisikan anjuran. Ungkapan berikut ini merupakan anjuran untuk ketua adat agar tidak melanggar atau melupakan adat yang sudah ada.

a. Rugi masahe

'Kepala kerugian' 


\section{b. Susu ma biji}

'Air susu ibu'

c. Namo lori

'Anak gadis'

Setelah mengidentifikasi ungkapn verbal dan nonverbal dalam upacara meminang gadis, pada bagian ini akan dianalisis makna budaya yang terkandung dalam ungkapanungkapan yang didapat dari data primer yaitu rekaman video dan wawancara dengan informan serta data sekunder yaitu data tertulis tentang upacara meminang gadis etnik Galela di Kokota Jaya. Pemaknaan budaya dalam penelitian ini didasarkan pada konsep D' Andarde yang membagi sistem makna budaya menjadi empat sistem, yakni: a) Representational, yaitu makna-makna mewakili dunia secara keseluruhan. b) Contsructive, yaitu makna-makna mengkreasikan kesatuan wujud atau keadaan. c) Directive, yaitu makna-makna menjadi pedoman seseorang dalam melakukan hal tertentu. d) Evacation, yaitu makna-makna sebagai pembangkit perasaan-perasaan tertentu.

\section{a. Ungkapan Verbal}

1. Suba Jou

'Sembah kepada Tuhan'

Makna budaya

Ungkapan ini mengandung makna directive, dimana ungkapan ini menunjukan bahwa Sembah kepada Tuhan, masyarakat etnik Kokota Jaya percaya bahwa Tuhan adalah segalanya. Sesuatu yang terjadi dari awal hingga tahap peminangan dapat berlangsung adalah karena Tuhan telah mengaturnya.

2. Hino wosa no

'Datang masuk kemari'

Makna budaya

Makna yang terkandung dalam ungkapan ini adalah constructive, untuk mengajak para rombongan pelamar dari pihak mempelai laki-laki untuk masuk ke dalam rumah mempelai perempuan dalam upacara meminang yang akan mulai berlangsung pada saat upacara adat.

3. Ai Dodihimo, Ria de i gia nongoru, awa de o bira

'Orang tua, kaka dan adik, saudara dan saudari' 
Makna budaya

Makna dari ungkapan ini ialah constructive, yakni bahwa setiap rombongan pelamar yang hadir, sudah mau meluangkan waktu dan kesempatan dalam upacara adat meminang gadis etnik Galela di kokota Jaya, menandakan adanya kerendahan hati. Sehingga mau terlibat langsung dalam upacara adat meminang gadis.

\section{Jojo ka mi gila gilano}

'Baik, kita mau masuk'

Makna budaya

Ungkapan ini memiliki makna evacation, yakni mengiakan bahwa rombongan pelamar dari pihak laki-laki akan menghargai ajakan dari pihak mempelai perempuan untuk masuk ke dalam tempat yang telah disediakan oleh pihak mempelai perempuan dalam upacara adat meminang gadis

\section{Ni matameka kagena}

'Kalian, duduklah disitu'

Makna budaya

Makna yang terkandung dalama ungkapan ini adalah constructive, mempersilakan duduk kepada rombongan pelamar yaitu dari pihak mempelai laki-laki untuk menduduki tempat yang telah disediakan oleh pihak mempelai perempuan dalam upacara adat meminang gadis.

6. Ngeko maseredi

'Pembuka jalan'

Makna budaya

Ungkapan ini mengandung makna consructive, Pembuka jalan yang berbentuk uang Tunai senilai Rp. 100.000 yang bermakna membuka halangan yang ada dijalan ketika para rombongan pelamar datang menuju rumah anak gadis keluarga.

\section{Uru mabobelenga}

'Pembuka mulut'

Makna budaya

Ungkapan ini mengandung makna constructive, Pembuka mulut yang berbentuk Uang Tunai senilai Rp. 50.000 yang maknanya untuk membuka mulut agar dapat berbicara ke para Dewan adat pihak kelurga perempuan untuk memulai berbicara dihadapan hadirin rombongan keluarga pelamar. 


\section{Ngihi madagali}

'Pengganti tempat'

Makna budaya

Ungkapan ini mengandung makna consructive, bahwa tempat anak gadis mereka yang akan keluar dari rumahnya dan Pengganti tempat dalam etnik Galela ketika anak gadis mereka mau keluar dari rumah setelah dipinang oleh keluarga pihak laki-laki dan orang tua dari pihak perempuan akan meminta syarat adat berupa uang Rp. 3.000 .000 sebagai penganti tinggal di pihak keluarga laki-laki.

\section{Jojo mi matame ka}

'Baik, kita akan duduk'

Makna budaya

Ungkapan ini memiliki makna evocation, yakni untuk mengiakan ajakan dari pihak mempelai perempuan agar rombongan pelamar atau pihak dari mempelai laki-laki, bahwa mereka rombongan pelamar dengan penuh kerendahan hati telah duduk. Dan siap untuk mengikuti upacara adat yang akan berlangsung.

10. Rugi masahe

'Kepala kerugian'

Makna budaya

Ungkapan inimengandung makna constructive, dimana ungkapan ini meminta kerugian atau mas kawin anak gadis mereka, ketika di pinang oleh rombongan keluarga laki-laki, kepala kerugian biasanya adalah 1 Lusin piring dan 1 pes Kain.

\section{Susu ma biji}

'Air susu Ibu'

Makna budaya

Ungkapan ini mengandung makna constructive, bahwa dalam upacara adat untuk membayar air susu ibu atau keringat lelah seorang ibu yang telah menyusui dan membesarkan anak gadis mereka sampai dipinang oleh keluarga lelaki.

\section{Namo lori}

'Burung air'

Makna budaya

Ungkapan ini memiliki makna constructive, yakni burung air yang biasanya disampaikan dengan Bahasa Galela yang diibaratkan seorang anak gadis itu seperti burung air bebas 
karena belum ada ikatan perkawinan yang diikatkan oleh orang tuanya sehingga masih bisa dipinang oleh pihak keluarga laki-laki.

Ungkapan nonverbal dalam acara adat ini menjadi gerakan tubuh, material dan makanan menurut teori Rakhmat (1994) dan Foster dan Anderston (1978). Dalam penelitian ini ditemukan beberapa jenis ungkapan nonverbal berdasarkan teori Rakhmat (1994) yakni:

a. Pesan kinesik yang terbagi menjadi tiga komponen, tetapi dalam penelitian ini ditemukan dua komponen yaitu:

1. Pesan gestural: berjabat tangan. Ini dilakukan oleh Kap dan Kal ketika selesai upacara meminang. Dikarenakan lamarannya sudah diterima oleh pihak mempelai perempuan.

2. Pesan postural: berjalan kaki, dan tidak memakai alas kaki. Ini dilakukan oleh rombongan pelamar, dengan menghargai adat yang sudah ada sejak turun-temurun sehingga rombongan pelamar tidak memakai alas kaki.

b. Pesan artifaktual: kain kebaya, salendang. Pakaian ini dipakai oleh rombongan pelamar untuk menghargai adat yang sudah ada sejak dahulu. Bahkan dapat membedakan dari salendang rombongan pelamar pakai. Kalau salendangnya disilang kekanan itu menandakan sudah menikah sedangkan kekiri belum menikah.

c. Pesan fasial: ekspresi wajah senang. Dalam hal ini para rombongan pelamar senang karena lamaran mereka dapat diterima oleh pihak mempelai perempuan.

Ungkapan nonverbal menurut Foster dan Anderston (1978) mencakup material dan makanan, dalam hal ini makanan adat. Di dalam penelitian ini ditemukan ungkapan nonverbal berdasarkan teori tersebut yakni: salopa, kabilano, olelenga, tatana, o baro, o tabako, o pipi, o mokuru, o bido, dan o dofahe.

b. Ungkapan Nonverbal

1. Ungkapan nonverbal berbentuk gerakan tubuh

a. Berjalan kaki

Makna budaya

Gerakan ini memiliki makna constructive, Para rombongan pelamar berjalan kaki menuju rumah dari pihak mempelai perempuan untuk upacara adat kebudayaan.

b. Tidak mengenakan alas kaki

Makna budaya 
Pesan nonverbal ini menunjukan makna constructive, penghormatan kepada pihak mempelai perempuan yang mana anak mereka masih gadis dan ini juga adalah salah satu simbol dari adat etnik Galela yang ada di Kokota Jaya.

2. Ungkapan nonverbal berbentuk material yang juga mencakup makanan adat

a. Salopa

Makna budaya

tempat pinang yang besar mengandung makna constructive, yang digunakan pada upacara adat peminangan untuk meletekan perlengkapan makan pinang. Salopa di bawah oleh pihak keluarga laki-laki ketika upacara peminangan.

b. Kabilano

Makna budaya

Kabilano adalah tempat pinang mengandung makna constructive, yang kecil yang digunakan pada upacara adat peminangan untuk meletekan perlengkapan makan pinang. Kabilano diletakan diatas meja oleh pihak keluarga perempuan ketika upacara peminangan.

c. O lelenga

Makna budaya

O lelenga adalah piring yang mengandung makna constructive, sebagai media yang digunakan untuk meletakan uang untuk membayar secara adat kepada pihak keluarga perempuan.

d. Tatana

Makna budaya

Tatana mengandung makna constructive, merupakan bentuk permainan yang telah menjadi budaya di setiap acara peminangan anak gadis, Tatana artinya Tukar menukar hadiah yang dapat dimakan dalam bentuk Waji, Halua, Poroci Sigi, Tikar dan sebagainya, Tatana hanya dilakukan oleh pihak keluarga perempuan kepada pihak kelurga laki-laki dan pihak kelurga laki-laki akak membayar dengan uang atas tatana apa yang diberikan oleh pihak keluarga perempuan.

e. O baro

Makna budaya 
O Baro artinya kain, yang mengandung makna constructive, digunakan untuk melengkapi Kepala kerugian dan sebagai pembungkus atau juga penutup Uang yang diberika oleh pihak keluarga laki-laki kepada pihak kelurga perempuan.

f. O tabako

Makna budaya

Tabako atau rokok yang mengandung makna constructive, sebagai pelengkap makan pinang dalam acara peminangan gadis di keluarga perempuan.

\section{g. O pipi}

Makna budaya

O Pipi artinya uang yang mengandung makna constructive, untuk membayar denda dan syarat-syarat adat dalam upacara meminang

h. O mokuru, $\mathrm{O}$ bido, $\mathrm{O}$ dofahe

Makna budaya

Pinang, sirih, kapur yang mengandung makna constructive, sebagai pelengkap dalam acara peminangan tersebut. Babak pembicaraan ini dari suatu tahapan peminangan akan dimulai setelah dibuka dengan makan pinang.

Berdasrkan teori sistem makna budaya D'Andarde (1984) maka dapat diketahui dalam upacara meminang gadis etnik Galela di Kokota Jaya sebagian besar bermakna constructive, yang berarti bahwa dalam meminang gadis etnik Galela di Kokota Jaya sadar akan kebudayaan mereka dan juga masih mempertahankan bahasa dan budaya yang diwariskan secara turun-temurun, yang telah terungkap dalam ungkapan verbal dan nonverbal. Melalui penelitian ini juga dijelaskan bahwa makna budaya directive tidak ditemukan dalam ungkapan nonverbal, hal tersebut menunjukan bahwa masyarakat Kokota Jaya berpegang pada ajaran-ajaran yang bersifat lisan.

\section{Kesimpulan}

Bentuk lingual dan makna leksikal ungkapan dalam upacara meminang gadis etnik Galela di Kokota Jaya ditemukan bentuk kata dan maknanya, bentuk frasa dan maknanya, bentuk klausa dan maknanya, serta bentuk wacana. Dalam wacana ditemukan pada syair. Kemudian 4 ungkapan diantaranya: ungkapan salam, ungkapan menghormati, ungkapan mempersilakan duduk dan ungkapan menghargai. Dengan ditemukan bentuk-bentuk seperti yang disebutkan diatas maka penelitian ini hasilnya seperti yang dikemukakan oleh Sugono (2015), terdiri atas bentuk dan makna, yang didalamnya terdiri atas kata, frasa, 
klausa dan wacana. Hasil penelitian ini menyangkut teori tersebut. Makna budya yang tersirat dalam ungkapan verbal dan nonverbal dalam upacara meminag gadis etnik Galela di Kokota Jaya ialah mengendung makna constructive, yaitu makna-makna kesatuan wujud atau kebudayaan dari masyarakat Kokota Jaya, directive, yaitu makna-makna yang menjadi pedoman untuk masyarakat Kokota jaya, evocation, yaitu makna-makna sebagai pembangkitan perasaan masyarakat Kokota Jaya. Dalam ungkapan verbal yang ditemun 9 makna constructive, 1 makna directive, dan 2 makna evocation. Di dalam ungkapan nonverbal tidak ditemukan makna budaya directive. Penelitian ini hasilnya seperti yang dikemukakan oleh D’Andarde (1984) Yuzar (2005) dan Rakhmat (1994) yaitu sistem makna budaya dari ungkapan-ungkapan verbal dan nonverbal. Hasil penelitian ini menyangkut teori tersebut.

\section{DAFTAR PUSTAKA}

Akmadjian, A., R.A Demers, dan R.M Harnish. 1981. Linguistics, An Introduction to language and Communication. Cambridge London : The M.I.T. Press.

Aslinda, dan Syafyahya, L. 2010. Pengantar sosiolinguistik. Bandung: PT Refika Aditama

Austin, J.L. 1962. How to do things with words. Oxford University Press New york.

Casson, R.W. 1981. Language, Culture, and cognition: Anthopological

Perspectives. New York: Macmillan Publishing Co, Inc.

Chaer, Abdul. 2007. Leksikologi dan Leksikografi Indonesia. Jakarta: Rinake cipta.

D’Andarde, R. G. 1984. Culture Theory. Essay on Mind. Self, and Emotion, Fleh.

Editor Richard A. Shweder and Robert A. Levine. London University.

Departemen Pendidikan dan Kebudayaan , Pusat Penelitian Sejarah dan Budaya Proyek Penelitian dan Pencatatan Kebudayaan daerah 1978/1979, Adat dan Upacara Perkawinan Daerah Dsulawesi Tengah, Palu. Palu. 1991. Tata Sajian Upacara Adat Suku Kaili,Museum Negara Propinsi Sulawesi Tengah.

Duarmas, 2006, Gaya bahasa kiasan dalam foruk perkawinan adat masyarakat Tanimbar. Tesis program pascasrjana Universitas Sam Ratulangi Manado.

Djajasudarma, T.F. 1994. Wacana: Pemahaman dan hubungan Antarunsur. PT Eresco. Bandung. 
Deend, D. 1987. Adat dan Upacara Perkaeinan di Minahasa, Laporan Penelitian, Manado: Universitas Sam Ratulangi.

Folley, W .A. 1997. Anthropological Linguistics: An Introduction. Malden: Blackwell Publishers Inc.

Gobel, H. 2012. Ungkapan bermakna budaya dalam syair Tarian Dangisa Masyarakat Bolango di Bolaang Mangondo Selatan. Tesis Program Pascasarja Universitas Sam Ratulangi Manado.

Goodenough, W .H. Anthropology Linguistics. In P.L. Garvin, ed. Report of The

7 Annual Raund Table meeting on Linguistics and Language Study. Georgetown University Press. Washington.

Havilaland, W .A. 1985. Antropologi. (Penerjemah: Soekadijo, R.G.) Penerbit Erlangga, Jakarta.

Hente, A. 1991. Laporan Penelitian Sistem Perulangan Bahasa Pamona. Palu. Pusat Pembinaan dan Pengembangan Bahasa Departemen Pendidikan dan Kebudayaan. Palu.

Heraty, T. 1984. Aku dalam Budaya. PT Dunia Pustaka Jaya. Jakarta.

Hudson, R.A. 1980. Sociolinguistics. Cambridge University Press. Cambridge.

Hymes, D.H. 1964. Language in culture and society: A Reader in Linguistics and Anthropology. New York: Harper \& Row. . 1974. Foundation in Sociolinguistics: An Ethnographic

Approach. University. University of Pennsylvania Press. Philadelphia.

Ingkiriwang, K.1981. Adat Perkawinan Masyarakat Toulour di Minahasa, Laporan Penelitian. Universitas Sam Ratulangi. Manado.

Joos, M., 1967 . The Five Clooks. Hertcourt Brace World Inc. New York. 